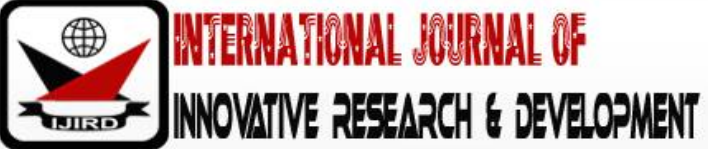

ISSN 2278 - 0211 (Online)

\section{Small-Scale Irrigation Farming Interventions in Turkana County, Kenya}

\author{
Dr. Jane Naliaka Situma \\ Lecturer, Department of Nutritional Sciences, \\ Masinde Muliro University of Science and Technology, Kenya \\ Dr. Jacob W. Wakhungu \\ Professor, Department of Disaster Management and Sustainable Development, \\ Masinde Muliro University of Science and Technology, Kenya \\ Dr. Edward M. Neyole \\ Senior Lecturer, Department of Disaster Preparedness Engineering and Management, \\ Masinde Muliro University of Science and Technology, Kenya
}

\begin{abstract}
:
Kenya relies heavily on rain-fed agriculture for food production. About $80 \%$ of Kenya's population live in rural areas and depend directly or indirectly on agriculture for their livelihoods. Agriculture continues to be the leading sector in the Kenyan economy in terms of its contribution to real GDP. Over-dependence on rain-fed agriculture is one of the major problems in Kenya's agricultural sector. Turkana County is a region of soils of high agricultural potential but aridity hinders its exploitation. It is characterized by scarce, erratic rainfall patterns. In the Kenya Vision 2030, under the economic pillar, increasing the land under irrigation is one of the key areas under agriculture sector. It aims at improving food security and household income which could contribute to nutrition security consequently to a healthy population that is competitive globally and has high quality of life. Small-scale irrigation has been practiced in Turkana for several years; however, there is scanty information about the effect of this irrigation on the nutrition status of the pre-school children. The current study investigated the small-scale irrigation farming interventions in Turkana County. The objectives of the study were to; determine socio-economic characteristics of households in Turkana County and evaluate food crop production via irrigation. Research design used was cross-sectional survey design. Purposive and cluster sampling were used. The study sample size was 420 comprising of 210 households practicing irrigation and 210 not practicing. Primary data were collected through structured questionnaires, key informant interviews, Focused group discussions and observations. Data was analyzed using descriptive and inferential statistics. The following computer software was used in data analysis; statistical software for social sciences. Qualitative data was analyzed into frequency distribution and Spearman's rank correlations. Foods mainly produced via irrigation were legumes and nuts $(68.1 \%)$, grains, roots and tubers $(66.7 \%)$. It is recommended that creating enabling institutional and economic environments is a major prerequisite to successful irrigation farming interventions. There is also need to enhance production of fruits and vegetables in the current study area.
\end{abstract}

Keywords: Small scale, irrigation, agriculture

\section{Introduction}

According to the Ministry of Agriculture, there have been several efforts to introduce irrigation in arid and semi arid areas by the government and non-governmental organizations (MoA, 2010a). The potential for irrigation in Turkana County is high because of the fertile soils and huge tracks of land that have room for development. Rivers Turkwel and Kerio hold the key to unlocking this potential, as well as the streams scattered all over the region. Another source that has not been exploited is underground water (Akuja, 2007). The area may not require advanced irrigation technologies, like the drips and fertigation used in the Middle East and North Africa; simple canals and basins will do (MoA, 2010b). As such, the current study sought to establish food crop production by irrigation and how it contributes to nutrition status of the pre-school children. Turkana is in arid and semi arid region, an area of high agricultural potential but aridity is among factors that hinders its exploitation (MoPND, 2010). It experiences frequent, successive and prolonged drought. The County has low and erratic rainfall patterns with frequent failures. With climate change, the traditional livestock management systems have suffered a great deal. Irrigation can play a significant role in alleviating food security in places like Turkana. The high burden of crop failure in Turkana is not only a threat to achieving Millennium Development Goals and Kenya Vision 2030 but also a clear indication of inadequate realization of human rights. 


\subsection{Research Design}

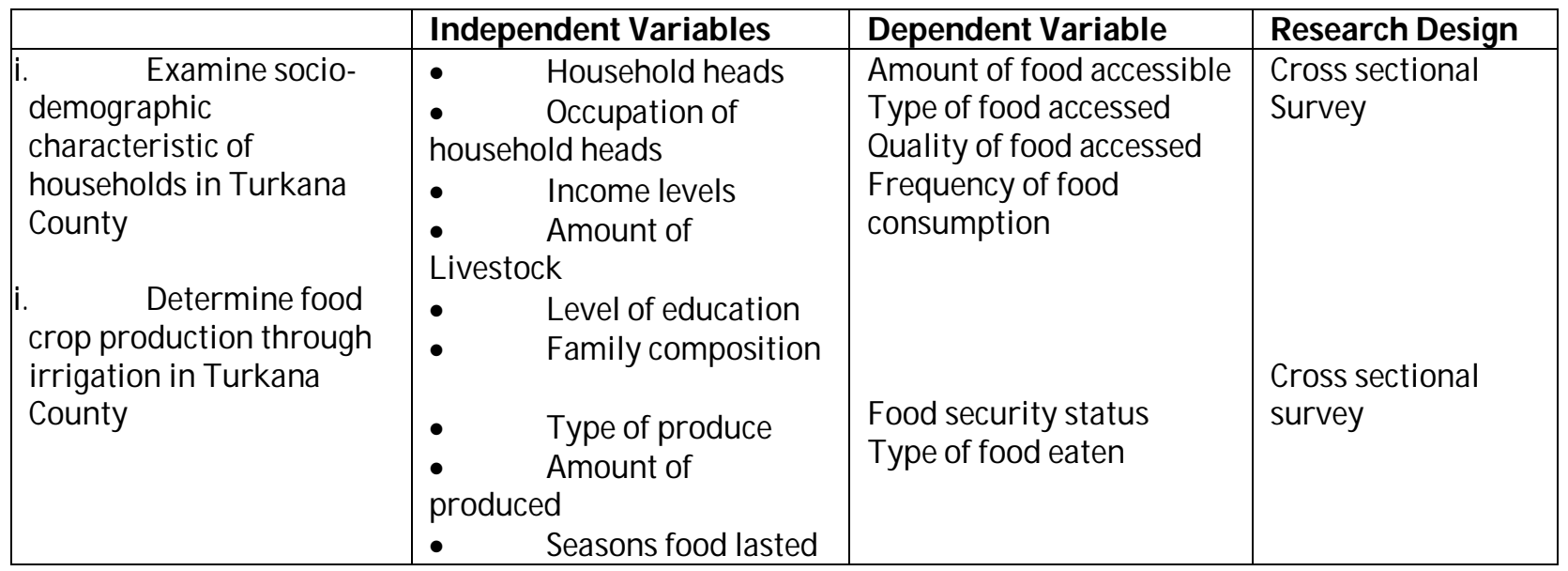

Table 1: Summary of Research Designs; Specific Objective and Variables

\subsection{Sampling Strategy}

Area of study was divided into nine strata based on administrative regions; Kaitilu (60 households), Lokori (60 households), Kainuk ( 80 households), Lokichar (100 households), Central (20 households), Kerio (20 households), Turkwel (20 households), Kalokol (20 households) and Lokitaung (40 households). Stratified random sampling was used to sample households in each stratum. Proportionate allocation was used to determine sample size from each stratum. In selecting key informants from various ministries and departments, NGOs and agencies purposive sampling was used.

\subsection{Sample Size}

Stratified random sample size of households was determined by use of Fishers' et al formula (Orodho, 2004).

$$
\mathrm{N}=\frac{\mathrm{Z}^{2} \mathrm{pq}}{\mathrm{d}^{2}}
$$

Therefore, the stratified sample size was to be;

$\mathrm{N}=1.96^{2} \mathrm{X} 0.273 \mathrm{X} 0.727 / \quad 0.05^{2}$

$=304$ households

This was the minimum sample size for the precision set for estimates derived from strata sample data. However, to avoid loss of data due to non response and to maintain precision, 420 households were sampled through stratified random sampling and 420 households were realized for data analysis.

\subsection{Data Collection Instruments}

\begin{tabular}{|c|c|c|c|c|}
\hline Study Population Unit & $\begin{array}{c}\text { Sampling } \\
\text { Method }\end{array}$ & $\begin{array}{c}\text { Sample } \\
\text { Size }\end{array}$ & $\begin{array}{c}\text { Data Collection } \\
\text { Instruments }\end{array}$ & $\begin{array}{c}\text { Appendix } \\
\text { Number }\end{array}$ \\
\hline Households & $\begin{array}{c}\text { Systematic } \\
\text { random }\end{array}$ & 420 & $\begin{array}{c}\text { Structured questionnaire } \\
\text { Observation checklist }\end{array}$ & \\
\hline $\begin{array}{c}\text { Key informants } \\
\text { (Ministries of, Agric., } \\
\text { Livestock and Fisheries, } \\
\text { Water and Irrigation } \\
\text { Special Programme,) }\end{array}$ & Purposive & 18 & $\begin{array}{c}\text { Key informant interview } \\
\text { schedule }\end{array}$ & \\
\hline
\end{tabular}

Table 2: Summary of Data Collection Instruments

\subsection{Ethical Considerations}

The study was approved by the Board of Postgraduate Studies of MMUST and the National Commission of Science and Technology. Verbal consent was obtained from the District Commissioners, Turkana Central, North and South Districts. Verbal consent was sought on the understanding that their identity would be anonymous and information received would be confidential.

\section{Results}

\subsection{Household Head}

The results show that in most of the households, fathers were the heads of the households where those with irrigation had $52.2 \%$ while those without irrigation had $49.2 \%$. About $20 \%$ of households were headed by children with more coming from non irrigation sites (22.5\%) compared to irrigation sites (19.4\%). The Chi square test of independence gave $\mathrm{X}^{2} 2,0.05=4.806$. Comparing this calculated Chi square with tabulated Chi square (5.999). This demonstrates that there was no significant ( $p>0.05$ ) association between the irrigators and non irrigators and household headship. The Chi 
square of deviation showing distribution of headship among all households irrespective of irrigation status was $\mathrm{X}^{2} 2,0.05=$ 2.8296, illustrates that there was no significant $(\mathrm{p}>0.05)$ differences among all the households studied in terms of household headship. Therefore, this implies that household headship cannot be a confounding variable in determining the effect of irrigation. Comparing these study findings with the KNBS (2010) report, there is contrast as the study did not report household headship by children. Relating the two, both reported high percentage in male headship where KNBS (2010) had 66.1\% against 33.9\% female headship.

\subsection{Occupation of the Household Heads}

The results presented in Table 3 point out that considerable proportion $(27 \%)$ of the household heads were laborers on their own farm whereas $40.9 \%$ were practicing irrigation. This was followed by livestock herding (19.5\%) and agricultural labor (18.0\%). A few (8.5\%) heads of the household were formally employed with a higher proportion (9.1\%) from the survey sites where irrigation is practiced. The unemployed respondents represented $3.0 \%$ of the total with a higher contribution of 3.8\% from the households not engaged in small-scale irrigation. Waged labor represented $5.3 \%$ with a higher proportion from small-scale irrigation sites. The least occupations included mining, brewing and weaving with a proportion of $0.4 \%$ each

\begin{tabular}{|c|c|c|c|c|c|c|}
\hline \multirow{2}{*}{$\begin{array}{c}\text { Occupation of the } \\
\text { Head of the } \\
\text { Household }\end{array}$} & \multicolumn{4}{|c|}{ Small-Scale Irrigation } & \multicolumn{2}{c|}{ Total } \\
\cline { 2 - 5 } & \multicolumn{2}{|c|}{ YES } & \multicolumn{2}{c|}{ NO } & \multicolumn{2}{c|}{ N } \\
\hline Own farm labor & 95 & 45.2 & 27 & 12.9 & 122 & 29.1 \\
\hline Agricultural labor & 23 & 11.0 & 54 & 25.8 & 77 & 18.4 \\
\hline Livestock herding & 33 & 15.7 & 41 & 19.6 & 74 & 17.7 \\
\hline Employed & 17 & 8.1 & 20 & 9.6 & 37 & 8.8 \\
\hline Petty trade & 8 & 3.8 & 16 & 7.7 & 24 & 5.7 \\
\hline Waged labor & 10 & 4.8 & 13 & 6.2 & 23 & 5.5 \\
\hline Unemployed & 5 & 2.4 & 10 & 4.8 & 15 & 3.6 \\
\hline Student & 6 & 2.9 & 4 & 1.9 & 10 & 2.4 \\
\hline House wife & 2 & 1.0 & 7 & 3.3 & 9 & 2.1 \\
\hline Merchant/ trader & 1 & .5 & 5 & 2.4 & 6 & 1.4 \\
\hline Domestic help & 2 & 1.0 & 3 & 1.4 & 5 & 1.2 \\
\hline Fishing & 1 & .5 & 4 & 1.9 & 5 & 1.2 \\
\hline Wood/ charcoal sell & 2 & 1.0 & 2 & 1.0 & 4 & 1 \\
\hline Hunt and gathering & 2 & 1.0 & 1 & .5 & 3 & .7 \\
\hline Weaving/ basketry & 1 & .5 & 1 & .5 & 2 & .5 \\
\hline Mining & 0 & 0 & 1 & .5 & 1 & .2 \\
\hline Brewing & 1 & .5 & 0 & 0 & 1 & .2 \\
\hline Total & 210 & 100 & 210 & 100 & 420 & 100 \\
\hline
\end{tabular}

Table 3: Occupation of the Household Heads in Turkana County, Kenya

Hunting and gathering were also not common (0.5\%). The study findings contrasted KNBS (2010) report which points out that the percentage distribution of adult women and men according to current and usual employment as $57 \%$ of women and $86 \%$ of men categorized as currently employed. According to KNBS (2010), current employment status for women by province shows that women from Rift Valley province have the higher chance of being employed (57.6\% are currently employed). Women who are divorced, separated, or widowed have the highest proportions employed (80 \%), followed by those who are married (64\%), and only $35 \%$ of the never-married are employed. This little variation in employment could be attributed to regional differences and also cultural issues within the community studied.

The calculated Chi square test of association gave $\mathrm{X}^{2} 16,0.05=67.391$ while the tabulated value is 27.587 . This shows that there was significant $(\mathrm{P}>0.05)$ association between occupation of the head of the household and the irrigation status of the household. A test of deviation to analyze occupation distribution across the irrigation status among the households doing and not doing irrigation indicated that there was significant $(\mathrm{P}<0.05)$ difference with $\mathrm{X}^{2} 16,0.05=$ 39.912. This is implying that occupation distribution among the households in Turkana County could influence the findings of the current study as it was significantly variably distributed among the households in relation to the irrigation status

\subsection{Livestock Ownership by Households}

Many of the households in all survey sites reported that they owned livestock. Those doing irrigation registered the highest percentage (88.1\%) of households owning livestock while $86.2 \%$ of households not doing irrigation were owning livestock (Figure 4. 3). Of the households that reported ownership of livestock irrigation sites had the highest percentage (58.7\%) of households with an increase in the size of their livestock in the six months prior to the survey. In non irrigation sites, $39.4 \%$ of the households recorded an increase. Most of the livestock increase was due to animals giving birth. As for the reduction in the size of livestock, a smaller percentage of households reported a decrease compared to the proportion of households reporting an increase; irrigation sites $47.8 \%$ and $38.2 \%$ for non irrigation sites. 


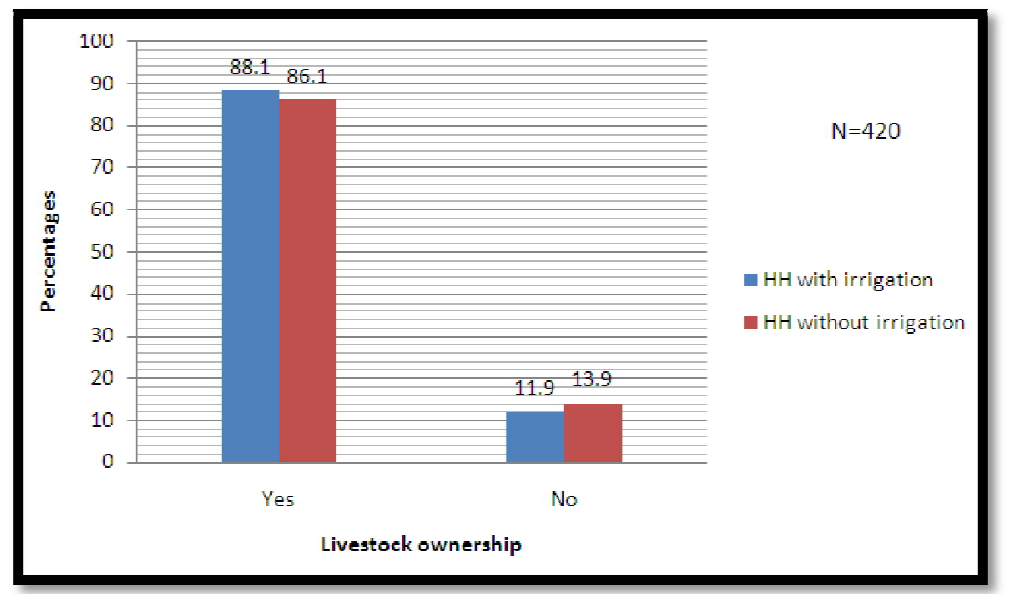

Figure 1: Livestock Ownership among Households

Most of the livestock reduction was reported to be as a result of death caused by either disease or drought. Other causes of reduction were sale and raids of livestock. For about one-tenth of the households in all the study sites, there was neither reduction nor increase in livestock.

According to FEWS NET (2010) report, Turkana County experiences frequent, successive, prolonged drought and cattle rustling, which lead to heavy losses of livestock. This is comparable with the current study findings. In addition, KFSSG (2010) reports that livestock diseases in Turkana County have depleted livestock. This corresponds with the current study findings. MoSP (2011) report explains further that failure of 2010 short rains and the resulting eight-month dry period led to declining herd sizes and conception of females in herds in Turkana. This provides one reason why some households had decreasing sizes of livestock.

The Chi square test of independence gave $\mathrm{X}_{1}{ }_{1}, 0.05=0.340$ while the tabulated value shows 3.841 . This shows that there was no significant $(\mathrm{P}>0.05)$ association between livestock ownership and the irrigation status of the household. A test of deviation to analyze livestock ownership distribution across the households practicing irrigation explains that there was no significant $(\mathrm{P}>0.05)$ differences across the households doing irrigation. The $\mathrm{X}^{2}{ }_{1}, 0.05=0.214$. This suggests that livestock ownership among households in the current study area may not influence the study findings as their ownership distribution was not significant across households.

\subsection{Use of Livestock among Households}

The results represented in the Table 4 designate that $39.8 \%$ of the households used the livestock for both sale and subsistence, while $30.0 \%$ mainly sold livestock and their products. Only 17.6\% reported using livestock and livestock products subsistently. Among those practicing irrigations, many of them (46.7\%) reported using livestock and livestock products subsistently and selling with a smaller proportion (15.2\%) reporting subsistent use.

\begin{tabular}{|c|c|c|c|c|c|c|}
\hline Livestock use & \multicolumn{9}{|c|}{ Small Scale Irrigation } \\
\hline & \multicolumn{2}{|c|}{ Yes } & \multicolumn{2}{c|}{ No } & Total \\
\hline & $\mathrm{N}$ & $(\%)$ & $\mathrm{N}$ & $(\%)$ & $\mathrm{N}$ & $(\%)$ \\
\hline Home & 32 & 15.2 & 42 & 20.0 & 74 & 17.6 \\
\hline Sale & 58 & 27.6 & 68 & 32.4 & 126 & 30.0 \\
\hline Both & 98 & 46.7 & 69 & 32.9 & 167 & 39.8 \\
\hline NA & 22 & 10.5 & 31 & 14.8 & 53 & 12.6 \\
\hline Total & 210 & 100 & 210 & 100 & 420 & 100 \\
\hline
\end{tabular}

Table 4: Livestock Use by Households

The calculated Chi square test of independence gave $\mathrm{X}_{3}{ }_{3}, 0.05=8.709$ whereas tabulated Chi square show 7.815. This shows that there was significant $(\mathrm{P} \varangle 0.05)$ association between livestock and their products use and the irrigation status of the household. A test of deviation to analyze livestock use distribution across the households practicing irrigation explains that there was no significant $(\mathrm{P}>0.05)$ differences across the households doing irrigation. The $\mathrm{X}^{2}{ }_{3}, 0.05=6.033$. The study findings are related with what is in the Turkana MOPND (2010) report, which indicates that more than $50 \%$ of the households use livestock by selling it or selling its products. Comparing these findings to KNBS (2010) report, the results are dissimilar as it reports $73 \%$ livestock use at home. The dissimilarity could be attributed to scope of the study where KNBS (2010) had a wider scope compared to the current study and the community studied in the current study had limited source of livelihood.

\section{Food Crop Production via Irrigation}

\subsection{Food Crop Production via Irrigation}

From the Figure 2, many of the households $(68.1 \%)$ produced legumes and nuts while grains, roots and tubers were produced by $66.7 \%$ of the households. Generally, fruits and vegetables were produced by more than half of the 
households (58\% and 54.6\%, respectively). According to NIB (2003) smallholder schemes grow mainly food crops and vegetables. This concurs with current study findings where most of the households (68.1\%) were producing legumes and nuts while grains, roots and tubers were produced by $66.7 \%$ of the households.

The Chi square test of independence gave $\mathrm{X}^{2} 2,0.05=4.082$ for legumes and nuts against a tabulated value of 5.991 . This shows that there was no significant $(\mathrm{p}<0.05)$ association between households producing legumes and nuts as food crop. A chi square test of independence for grains, roots and tubers) production across the households was $\mathrm{X}_{2}^{2} \quad 0.05=$ 4.081. This shows that there were no significant $(p>0.05)$ association between households in production of grains, roots and tubers as food crops among households.

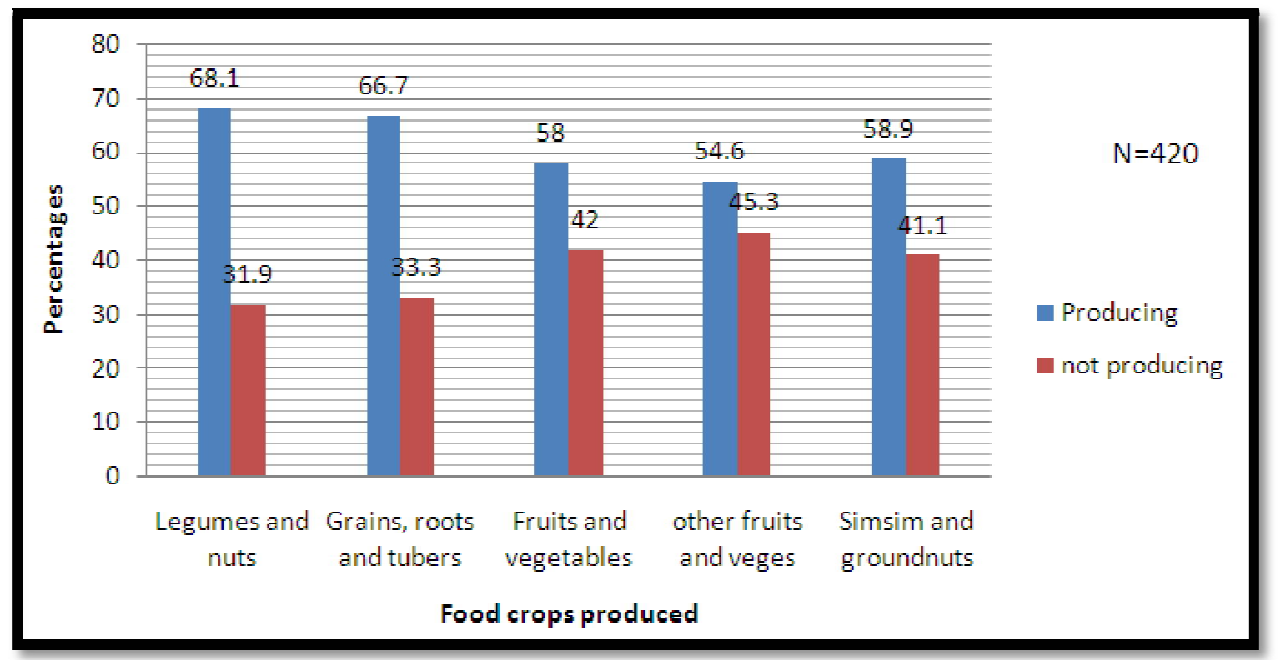

Figure 2: Food Crops Produced Via Irrigation

A test of deviation to analyze percentage distribution across the households in terms of legumes and nuts, grains roots and tubers, elucidate that there were no significant ( $p>0.05$ ) association across the households doing irrigation. The $\mathrm{X}_{4,0.05}=$ were 0.123 and 2.766 respectively. Chi square tests of independence for fruits and vegetables with vitamin A was $\mathrm{X}^{2}{ }_{4} 4.082$; other fruits and vegetables was 4.160 while simsim and groundnuts was $\mathrm{X}^{2}{ }_{4}$ at 4.160 . This reveals that there was no significant $(\mathrm{p}>0.05)$ association in production of fruits, vegetables, simsim and groundnuts and the households doing irrigation. Consequently, in the current study, type of food crops produced by households practicing irrigation cannot account for the results that were obtained in the current study.

According to MoPND (2010), Turkwel irrigation scheme is the oldest scheme in Turkana County and crops introduced during the scheme initiation were sorghum, maize, green grams, cowpeas, a variety of vegetables and fruits such as mangoes, citrus, bananas and dates (MoA, 2005). This is not what was observed in the field as there was less emphasis on fruits like bananas, dates and this could be due to the higher priority given to cereals and legumes. This was further supported by the 73\% of the key informants. Nevertheless, Ruel (2003) and Allen (2003) assert that one goal of small-scale irrigation farming interventions is to increase dietary diversity, conceptualized as "the number of different foods or food groups consumed over a given reference period".

\subsection{Amount of Food Crop Produced Via Irrigation by Households}

According to Figure 3, results from the structured interviews indicate that most (50\%) of the households produced on average 5-10 bags of all farms produce (cereals, legumes, simsim and nuts). A modest percentage (20\%) produced 1-5 bags. Minute households (10\%) produced less than one bag of total farm produce but secondary data from Ministry of Agriculture Turkana district (2010) report, indicate that many (38.8\%) of the households produced on average 5-10 bags of farm produce. A considerable percentage (34\%) produces 1-5 bags. Very few households (10.5\%) produced less than one bag of total farm produce. The variation in the primary data of the current study and secondary data from Ministry of Agriculture 2010 report could be due to the fact that primary data was specific to the study sites while secondary data was reflecting the whole Turkana County status, initially Turkana District.

As illustrated in Figure 3, 98.1\% of the households indicated that farm produce lasted only one season while 1.9\% of the households indicated that the food lasted two seasons. According to $90 \%$ of the members in the FGDs and $84 \%$ of the key informants, the produce lasted only one season and the produce was much below the potential and FGD members and key informants felt that there was need to invest more in the agricultural inputs and still the community needs to look at agriculture as an economic activity and not a social adventure. 


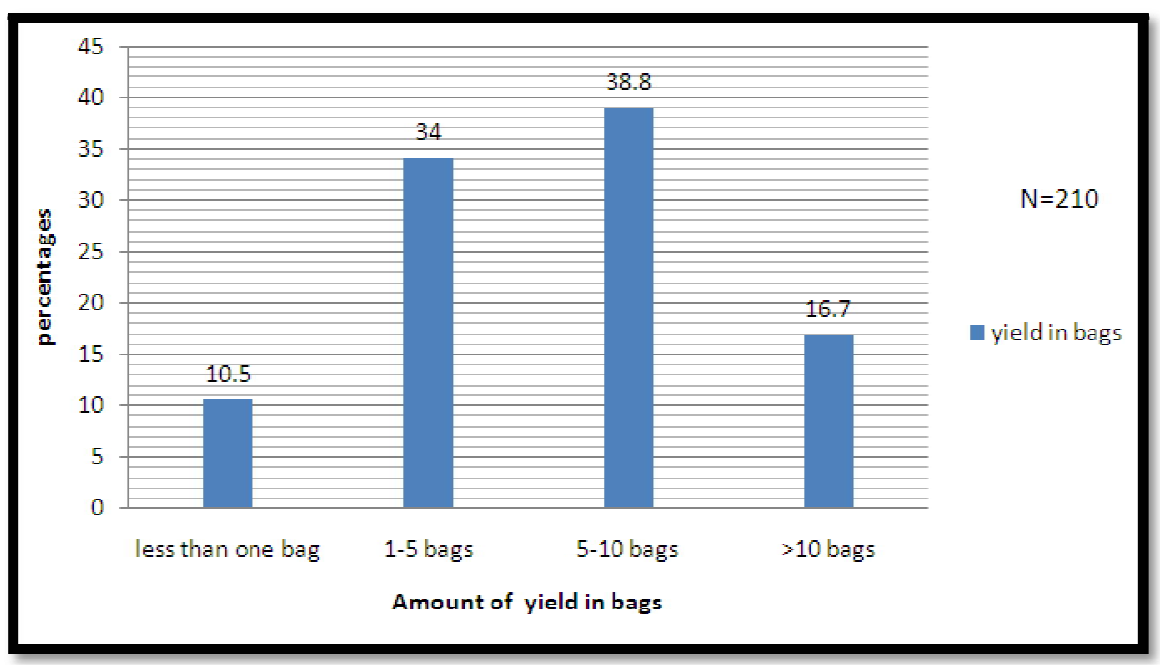

Figure 3: Farm Produce in Bags by Households

A Chi square test of deviation to analyze farm produce distribution across the households practicing irrigation indicated that there was no significant $\left(p>0.05\right.$ ) variation. The calculated $\mathrm{X}^{2} 3,0.05$ was 4.16 compared with the tabulated value of 7.815. This means that the amount of farm produce in bags that the household had in store may influence the current study findings. Enhancing productivity will draw a distinction better.

World Bank (2008), points out that crop yield under irrigation agriculture have doubling production and lasts all the year around. This is in contrast with the current study findings. The disparity could be in the technology adopted and the intensity of the farming. From observation soil and water conservation practices were still a challenge to these farmers. There could be need to invest more in the technology in particular, soil and water conservation to have more efficient utilization of water so that it can be used throughout the year. The low yields could also be associated to low use of fertilizer and improved crop varieties. This was gathered from KIIs mainly the agricultural extension officers. FAO (2010) acknowledges that indeed use of fertilizer and improved crop varieties are key to increasing crop yields.

\subsection{Number of the Seasons Farm Produce Lasted}

The findings indicated that $98.1 \%$ of the households pointed out that farm produce lasted only one season while $1.9 \%$ of the households designated that the food lasted two seasons. These findings concur with findings gathered from FGDs and Key informants' interviews which revealed that food produced from irrigation only lasts one season. Though irrigation has been proved to be a decisive factor in determining the development of agriculture and the rural economy (Friis et al., 2001), this was not the case with the findings of the current study. This seems to disagree with the irrigation farming interventions in Turkana county as improved availability of irrigation is supposed to bring positive changes in the land use pattern, cropping pattern, cropping intensity and adoption of various yield-augmenting inputs, all of which one way or the other help to increase the productivity of land substantially (Parry, 2009).

A Chi square test of independence to analyze the association for the distribution of the number of seasons that food lasted across the households practicing irrigation made clear that there was significant $(p<0.05)$ association with the calculated Chi Square of $\mathrm{X}_{1}^{2}, 0.05=4.16$ against a tabulated value of 3.841. This signifies that the duration that the farm produce lasted did influence the findings of the current study.

According to MoPND (2010) report, irrigation has increased supply of food grains and other agricultural commodities and has helped control prices of agricultural commodities which have benefited a large section of the community in the non-agricultural sector. These is in contrast with study findings as food produced according to the 56\% of the FGDs and $68 \%$ of the key informants, the amounts are not significant. The disparity in the significance of the food produced via irrigation could be attributed to the attitude of the key informants and FGD members with the aim of promoting food aid against own production.

\section{Conclusion}

Many households are still poor irrespective of their access to small-scale irrigation. Therefore there was minimal contribution of irrigation intervention towards economic empowerment of this community. This came out clearly in the FGDs that there are other correlates of poverty that must also be addressed in order for irrigation to have a lasting and deeper impact on food security. Issues like family size, level of education, health and community governance need to be addressed. Hence, access to irrigation is only one of the necessary services essential for increasing the productivity and income of small-scale farmers.

Foods produced through irrigation in these study areas were predominantly staples; maize sorghum and beans. Analysis of the types of foods consumed at the household level also revealed dependence on food aid commodities. Food aid plays an important role in fighting malnutrition. 


\section{Recommendations}

For irrigation to play a more important role in food production in the study area, it is recommended that there is need to create enabling institutional and economic environments to all allow intensive production of food crops that can improve the income of this community. There is need to enhance production of fruits and vegetables in the current study area which will contribute towards a diverse diet and contribute towards nutrition security. Diverse diets rich in micronutrients offer the ultimate sustainable solution to under nutrition.

\section{References}

i. Akuja, T. (2007). Arid food insecure regions can benefit from intensified irrigation programmes. Electronic document, http:/ / www.fao.org/ foodsecurityturkana/ , accessed May 27, 2011.

ii. Alaimo, K. Olson, C. Frongillo, E.and Briefel, R. (2001). Food insufficiency, family income and health in US preschool and school-aged children. American Journal of Public Health 91 (5): 781-786.

iii. Berti, R., Krasevec, J. and Sian, F. (2004). A review of the effectiveness of agriculture interventions in improving nutrition outcomes. Public Health Nutrition Journal 7(5):599-609.

iv. Bhattacharya, J., Currie, J. and Haider, S. (2004). Poverty, food insecurity and nutritional outcomes in children and adults. Journal of Health Economics 23(2): 839-862.

v. FAO (2004). The state of food and agriculture in the world 2004. Electronic document, http:/ / www.fao.org/ news/ story/ en/ item/ 8867/ , accessed May 27, 2011.

vi. FAO (2010). State of food security in the world. Electronic document, http:/ / www.fao.org/ hivaids/ , accessed May 27, 2011.

vii. FEWS NET (2010). National short rains assessment report 2010. Famine and early warning system Network. Nairobi, Kenya. Government of Kenya printers; 34-35.

viii. Hoddinott, J., Cohen, M. and Bos, M. (2003). Food Aid in the 21st Century: Current Issues and Food Aid as Insurance. FCND Discussion Paper no. 25, International Food Policy Research Institute: Washington, DC.

ix. IFPRI (2009). Climate change; impact on agriculture and costs of adaptation. Washington, DC, International Food Policy Research Institute; 435- 459.

x. KFSSG (2010). Turkana long rains assessment report. Kenya Food Security Steering Group 2nd quarter bulletin, Nairobi Kenya. Government of Kenya printers; 12-13.

xi. KFSSG (2011). Turkana short rains assessment report. Kenya Food Security Steering Group 1st quarter bulletin, Nairobi, Kenya. Government of Kenya printers; 18-24.

xii. KNBS (2010). Turkana District population distribution. Kenya National Bureau of statistics, Nairobi, Kenya. Government of Kenya printers; 711-785.

xiii. KNBS (2003). Kenya Demographic and Health Survey 2003. Central Bureau of Statistics and Ministry of Planning and National Development, Kenya. Government of Kenya printers; 307- 342.

xiv. KNBS and MoPHS (2008). Guidelines for Nutrition Assessments in Kenya. Kenya National Bureau of statistics and Ministry of Public Health and Sanitation. Afya house, Nairobi. Government of Kenya printers; 85-109.

xv. MoA (2010a). Food production based on cereal production in the districts for the year 2010; Ministry of Agriculture, Kilimo House Nairobi Kenya. Government of Kenya printers; 112- 167.

xvi. MoA (2010b). Turkana District Annual report for the year 2010. Ministry of Agriculture, Kilimo House, Nairobi Kenya. Government of Kenya printers; $43-78$.

xvii. Osmani, S. (1992). Nutrition and Poverty. Clarendon Press, Oxford, United Kingdom;183-194.

xviii. Parry, M. (2009). Climate change and the risk of hunger: the scale of the challenge and required response. Rome, World Food Programme; 37 -56.

xix. Ravallion, M. (1997). Famines and economics. Journal of Economic Literature, 35(3):1205-42.

xx. Reis, M. (2011). Food insecurity and the relationship between household income and children's health and nutrition in Brazil. Health Economics. Doi: 10.1002/ hec.1722-1756. 